\title{
Crohn Hastalığında Gelişen Komplikasyonlara Göre Değişen Tıbbi Beslenme Tedavisi: Bir Olgu Sunumu
}

\author{
A Case Report: Changing Medical Nutrition Therapy According to the Complications of Crohn's \\ Disease
}

\section{Güzin Tümer ${ }^{1}$}

Geliş tarihi/Received: 28.05.2018 • Kabul tarihi/Accepted: 15.07.2018

\section{ÖZET}

İnflamatuvar bağırsak hastalıkları (İBH), iki temel formuyla Crohn hastalığı (CH) ve Ülseratif Kolit (ÜK) olup gastrointestinal sistemde kronik, tekrarlayıcı inflamasyona neden olurlar. Bu hastalıklar genetik yatkınlık, çevresel ve immünolojik etmenlerin bir araya gelmesi sonucu, gastrointestinal florayı, barsağın tüm katmanlarını etkileyen, uyumsuz immün yanıtların tetiklendiği inflamatuvar olaylar dizisidir. CH ağız, özefagus, mide, bağırsak ve anüse kadar olan bölgede inflamatuvar aktivitelerle mukozayı etkilerken, ÜK yalnızca kolonik mukozayı etkiler. CH’ın etiyopatogenezi tam olarak anlaşılmamakla birlikte çevresel etmenlerden, sigara, enfeksiyon, apendektomi, emzirme süresi, beslenme alışkanlıkları, ilaçlar, sosyoekonomik etmenler ve stresle ilişkilidir. Bağışıklık sistemde önemli rol oynayan gen mutasyonunun otoimmün hastalıklara ve İBH’a neden olduğu bilinmektedir. Genellikle 15-30 yaş arası görülen CH, fistül, bağırsak tıkanıklığı ve karın içi abse gibi ciddi komplikasyonlar oluşturmaktadır. Hastaneye yatan CH'da \%75 beslenme yetersizliği ve ağır mikrobesin ögesi kayıpları görülür, özellikle emilim bozukluğu, intestinal kayıplar, besin metabolizmasındaki değişiklikler, inflamasyon şiddeti, bulantı, kusma, karın ağrısına bağlı tüketimin azalması/gereksinmenin artması, steroidlerin vitamin ve minerallere olumsuz etkisi, GI'in tutulum yeri, hastalıklı barsağın uzunluğu, rezeke edilmesi ve yine hastalığın alevlenme süresi/sıklığı, beslenme yetersizliğine, protein, vitamin, mineral, eser element kayılarına neden olmaktadır. CH'ın beslenme tedavisi remisyon ve aktif döneme, gelişen komplikasyonlara göre, cerrahi öncesi ve sonrasında değişkenlik arz eder ve dinamik bir süreçtir. Beslenme tedavisinin amacı atakları azaltmak, aktif dönemde vücut bileşimini korumak, makro ve mikrobesin ögeleri kayıplarını önlemek ve yerine koymak, yaşam kalitesini arttırmak olmalıdır. Bu makalede $\mathrm{CH}$ tanısı alan bir hastanın gelişen komplikasyonlara göre farklı beslenme tedavi stratejilerinin gerçekleştirildiği olgu tartışlmaktadır.

\section{Anahtar kelimeler: Crohn hastalı̆̆, beslenme tedavisi}

\begin{abstract}
Inflammatory bowel diseases (IBD) are Crohn's disease (CD) and Ulcerative colitis (UC) with two main form cause chronic, recurrent inflammation in the gastrointestinal tract. These diseases are thesequence of inflammatory events triggered by in compatible immunological responses that affect all layers of the gut, including gastrointestinal flora, genetic susceptibility, consequent taggregation of environmental and immunological factors. CD affects the mucosa by inflammatory activities in there gion as mouth, esophagus, stomach, intestine and anus; while UC affects only colonic mucosa. The etiopathogenesis of $\mathrm{CD}$ is not fully understood; smoking, infection, appendectomy, duration of breastfeeding, eating habits, medications, socioeconomic factors and stress are associated with CD. It is known that gene mutation, which plays an important role in
\end{abstract}


the immune system, is caused by auto immune diseases and IBD. CD seen usually between 15-30 years; it makes up serious complications; fistula, intestinal obstruction and intraabdominal abscess. Hospitalized CD has a 75\% nutritional deficiency and severe micronutrient losses; especially malabsorbsion, changes in nutrient metabolism, severity of inflammation, nausea, vomiting, increase in requirement's/decrease in consumption due to abdominal pain, adverse effect to steroids of vitamins and minerals, injury location of GI,resection, length of diseased gut and duration/frequency exacerbation of the diseaes, malnutrition, protein, vitamin, mineral, trace element losses cause by it. The nutritional therapy of $\mathrm{CD}$ may change and a dynamic process; according to remission and active rotation, before and after surgery developing complications. Nutritional therapy should be aimed at reducing the attacs, protecting the body composition during the active phase, preventing and replacing macro/micronutrient losses, and improving the quality of life. This article discusses the fact that different nutritional therapy strategies are performed according to developing complications of a CD who has a CD.

Keywords: Crohn's disease, nutritional therapy

\section{Gíriş}

Son dönem araştırmalarda inflamatuvar bağırsak hastalıkları (İBH)’nın sıklığının arttığı gösterilmiştir $(1,2)$. İBH'ı kentsel kesimde kırsal kesime göre daha fazla saptanırken, erişkinlerde Crohn hastalığ $(\mathrm{CH})$ insidansı 1-6/100.000, çocuklarda 0.2-1.3/100.000'dır $(1,2)$. CH'ın sıklığı etnik gruplara göre de farklıdır, beyazlarda zencilere göre, Yahudilerde orta Avrupa kökenli Yahudi olmayanlara göre daha sıktır. Turner sendromu, Hermansky-Pudlak sendromu ve glikojen depo tip1b, tip1 diyabet ve kistik fibroziste daha sık görülmektedir(3).CH'ıgastrointestinalsistemdeduvarı tutan, açıklık oluşturarak mukozal hasarı meydana getiren bir hastalıktır. Çoğunlukla kolon ve terminal ileumu birlikte ya da tek tek tutabilir, daha az oranda da özafagus, ince bağırsakları bölgesel olarak veya tümüyle tutabilir (4). Hastaneye yatırılan aktif CH'da \%75’ten fazla vücut ağırlığı kaybı gözlenmektedir. Negatif nitrojen dengesi, anoreksi, artmış intestinal kayıplar ve olguların \%50'den fazlasında steroide bağlı oluşan katabolizma, sistemik inflamasyon ciddi beslenme yetersizliğinin sebebidir. Tutulum bölgesi ve uzunluğu, hastalığın aktif dönem süresi ve sıklığı emilim bozukluğunu, besin ögesi yetersizliğini önemli derecede etkiler. $\mathrm{CH}$ alevlenmesinde görülen karın ağrısı, bulantı, kusma, ishal, sıvı-elektrolit, vitamin ve eser element kaybına neden olurken besin alımını, iştahı azaltarak kilo kaybını da hızlandırmaktadır (5). Ayrıca üst gastrointestinal sistemin tutulduğu CH’da yutma güçlüğü, epigastrik ağrl, bulantl, kusma ve erken doyma gibi belirtilerde görülebilir (1). CH'da anoreksiyanın sebebi proinflamatuvar sitokinler olarak düşünülmektedir. Proinflamatuvar sitokinlerden Tümer Nekroz Faktör-a (TNF-a), Interlökin (IL)-1 $\beta$, IL-6 ve besin alımını baskllayan leptindüzeylerininarttığıbulunmuştur.Busitokinlerin ağırlık, beden kütle indeksi (BKİ), serum albümin, transtretin düzeyleriyle negatif korelasyon gösterdiği saptanmıştır. Atak dönemindeki inflamasyon, ateş, enerji gereksinmesini arttırır, protein yıkımını tetikler $(4,6)$. İshalde düşük serum potasyum $\left(\mathrm{K}^{+}\right)$, magnezyum $\left(\mathrm{Mg}^{2}\right)$, kalsiyum $\left(\mathrm{Ca}^{+2}\right)$ ve fosfat düzeyleri tanımlanmıştır. Steatore ile ilişkili yağda eriyen vitaminlerin kaybı görülürken, steroid kullanımıyla kalsiyum emilimi baskılanır, magnezyum atımına ve protein metabolizmasının değişmesine bu da kas kaybına neden olmaktadır. D vitamini düzeyi olumsuz etkilenmektedir. Safra asitleri, $\mathrm{B}_{12}$ vitamini eksikliği ve düşük serum düzeyi ise, terminal ileum tutulumu veya rezeksiyonu sonrasinda mukozal hasar ve emilim yüzeyinin azalmasına bağlanmaktadır. Ayrıca oluşan fistüllerde çinko, sıvı ve elektrolit kaybına neden olur. CH'da görülen emilemeyen yağlar intestinal lümende kalsiyum ve magnezyumu bağlayarak atımını hızlandırırken, sulfasalazin folik asit emilimini ve dehidrofolat redüktazı azaltmaktadır. Demir eksikliği anemisi CH'da yüksek oranda mevcuttur. İnflamasyonla oksidatif sürecin başlaması, antioksidan olan selenyum, A, E ve C vitaminleri yetersizliğini de oluşturmaktadır (7). Substrat metabolizmasındaki değişiklik karbonhidrat oksidasyonunda azalmaya, lipit oksidasyonunda artmaya, yağsız vucüt kütlesinde azalmaya yöneliktir. 
$\mathrm{CH}$ çocuk ve adölesanlarda \%40 üzerinde büyüme geriliği, kas kütlesi ve vücut yağında \%60 azalma tanımlanmaktadır $\quad(5,8)$. Remisyondaki CH'ın beslenme durumu normal ya da şiddetli beslenme bozukluğunda olabilir. Beslenme yetersizliği varsa cerrahiden kaynaklanan malabsorbsiyona, safra asidine bağlı diyare ve steatoreyle ya da kısa bağırsak sendromu, aşırı bakteriyel çoğalmadan veya ilaç tedavisinden kaynaklanabilir. Bu dönemde özellikle $\mathrm{Ca}^{+2}$, demir, folat ve $\mathrm{B}_{12}$ vitamini izlenmeli ve ek olarak verilmelidir (9). Peri-operatif dönemde, hastada nekroze olan, mokozal hasarlı intestinal bölgenin rezeke edilmesi planlanır. Cerrahi öncesindeki beslenme yetersizliğinin zaman varsa düzeltilmesi, cerrahi sonrasında ise çıkarılan bölgeye ve uzunluğuna göre kısa bağırsak sendromu (KBS) düşünülerek tıbbi beslenme tedavisi geliştirilmelidir $(5,10)$.

CH'da Tubbi Beslenme Tedavisi: CH'da azalan oral alım, artmış besin ögesi gereksinimleri, besin ögesi kaybının fazla olması, ilaç-besin ögesi etkileşimi malnütrisyon ile sonuçlanabilir. Ağır beslenme yetersizliği hastalığın alevlenme sıklığını, sürecini, uzamasını ve inflamatuvar yanıtın oluşumunu katabolizma ve anoreksiya yönünden olumsuz etkilemektedir (10). CH'ın tıbbi beslenme tedavisi klinik seyre göre üç dönemdir:

1. Akut aktif $\mathrm{CH}$

2. Remisyon dönemi ve devamı

3. Peri-operatif dönem

$\mathrm{Bu}$ bölümde CH'ın farklı dönemlerde beslenme tedavisi aşağıdaki tabloda literatür bilgileri ışığında özetlenmeye çalışılmıştır (Tablo 1) (10-13).

\section{OLGU}

Olgu 1 çocuk annesi, 34 yaşında, 2017'de, şiddetli karın ağrısı, karında kramp, göbek deliği çevresinde ağrı, sürekli kusma ve bulantı şikayeti ile bir başka merkeze başvurmuş ve 20 günlük sürede apendektomi cerrahisiyle izlenmiştir. Bu sürede sadece mayi desteği ve rejim 1-2 almıştır. Şikayetlerin devam etmesi üzerine Ondokuz Mayıs Üniversitesi Araştırma
Hastanesi’ne gönderilmiştir.

Hasta 80 kg ağırlığında, BKİsi 34 kg/m²'dir, 20 gündür karın ağrısı, kusma, karında şiddetli kramp şikayeti bulunmaktadır ve oral alım çok azdır. Özgeçmişinde alerjik astım, hipotroidi, reaktif hipoglisemi, apendektomi bulunmaktadır. Kan bulgularından $\mathrm{Na}^{+}$, $\mathrm{K}^{+}, \mathrm{Ca}^{+2}$, Hemoglobin (Hb), Hematokrit (Hct), lökosit (WBC), eritrosit (RBC), C-reaktif protein (CRP) değerleri normalken, sedim, aspartat aminotransferaz (AST) ve alanin aminotransferaz (ALT) değerleri yüksektir. İdrarında protein, keton ve lökosit yüksek miktarda bulunmaktadır.

Bilgisayarlı tomografide (BT) mezenter iskemi, perferasyonla, acil cerrahi kararı verilmiştir. Trietz ligamentin $150 \mathrm{~cm}$ sonrası ileum $15 \mathrm{~cm}$ kalana dek (5-5.5 m) çıkarılmıştır. İleoçekalvalf ve kolon durmaktadır, iki anastomoz yapılmış ve ileostomi açılmıştır. Rezeke edilen barsağın patolojisi CH’la uyumlu bulunmuş ve KBS ile izlenmiştir.

Cerrahi sonrası 5 gün oral kesilmiş, elektrolitsıvı desteği (4000-5000 mL) yapılmıştır. Hastanın direnlerden, ileostomiden geleni, idrar çıktısıyla sıvı volümü belirlenmiş, günlük kan değerlerine göre, $\mathrm{NaCl}, \mathrm{KCl}, \mathrm{MgSO}_{4}$ eklenmiştir. Sonraki 3 günde rejim 1 ve $3000 \mathrm{~mL}$ parenteral beslenme (TPN, santral yol)+1000 mL sıvı desteği ( $\mathrm{NaCl})$ başlanmıştır. Son 1 ayda \%15 vücut ağırlığı kaybı (12 kg kayıp), (BKİ= $29 \mathrm{~kg} /$ $\mathrm{m}^{2}$ ) olmuştur. Cilt rengi soluk, halsizlik şikayeti vardır, nütrisyonel risk skoru (NRS) 4 olarak hesaplanmıştır. Acil ameliyat nedeniyle hastaya pre-operatif beslenme yapılamamış, 20-25 günlük açlık/çok az beslenme olduğundan refeeding sendromunu önlemek için düşük dozda enerji, protein başlanması düşünülmüş, aşağıdaki beslenme tedavisi uygulanmıştır.

Alması gereken enerji: Başlangıç $=20 \mathrm{kkal} / \mathrm{kg} / \mathrm{gün} \rightarrow 68$ $\mathrm{kg} \times 20 \mathrm{kkal}=1360 \mathrm{kkal} /$ gün

Toparlanma $=30 \mathrm{kkal} / \mathrm{kg} / \mathrm{gün} \rightarrow 68 \mathrm{~kg} \times 30 \mathrm{kkal}=2040$ $\mathrm{kkal} / \mathrm{gün}$

Alması gereken protein: Başlangıç $=1.2 \mathrm{~g} / \mathrm{kg} / \mathrm{gün} \rightarrow 68$ $\mathrm{kg} \times 1.2 \mathrm{~g}=81 \mathrm{~g} / \mathrm{gün}$

Toparlanma= $2 \mathrm{~g} / \mathrm{kg} / \mathrm{gün} \rightarrow 68 \mathrm{~kg} \times 2 \mathrm{~g}=136 \mathrm{~g} / \mathrm{kg} / \mathrm{gün}$ 
Tablo 1. Crohn hastalığında tıbbi beslenme tedavisi

Genel stratejiler

- IBH'da belirli bir diyet şekli bulunmamaktadır.

- Hastalığın normal seyrinde enerji-protein gereksinimi sağlıklı bireylerinki ile benzerdir.

- Sebze, meyve, n-3 yağ asit zengin, n-6 yağ asit düşük diyet IBH riskini azaltır.

- Anne sütü ile beslenme IBH riskini azaltır.

- IBH'ı beslenme durumu ve malnütrisyon açısından sürekli, düzenli izlenmelidir.

\begin{tabular}{ll}
\hline Evre & Beslenme tedavisi ve öneriler \\
\hline 1.Akut aktif CH & \\
\hline Enerji gereksinimi & $25-35 \mathrm{kkal} / \mathrm{kg} / \mathrm{gün}$ \\
Protein gereksinimi & $1.5-2.0 \mathrm{~g} / \mathrm{kg} / \mathrm{gün}$ \\
Diyet posası & Düşük \\
Şiddetli ishal, kusma, ostomi/fistül gelen $\uparrow$ & Slvl-elektrolit parenteral infüzyon \\
Yetersiz oral alım (ilk tercih oral) & Nazogastrik, nazojejunal tüplü beslenme \\
Bağırsak stenoz/obstrüksiyon gelişmesi durumu & Stenoz distaline tüple enteral beslenme \\
Oral/enteral yetersiz (Gastrointestinal disfonksiyon, KBS* durumu) & Oral + enteral + parenteral beslenme \\
Enteral ürün & Standart, polimerik/plus \\
Fistül debisi yüksekse & Ağırlıklı total parenteral beslenme \\
Uzun süre yetersiz beslenme & Refeeding sendromu, düşük doz başlama \\
Probiyotik kullanımı & Kullanılmamalı \\
Steroid tedavisi (Osteopeni, osteoporosis) & Ca², D vitamini, Mg2 izlenmeli, ek yapılmalı \\
Kolestramin ilaç (yağ malabsorbsiyonu) & Steatore izlemi \\
\hline
\end{tabular}

\section{Remisyon dönemi}

\section{Beslenme durumu, malnütrisyon}

Malnütrisyonda alım yetersiz ise

Diyet posası

Probiyotik, n-3 supplement

Süt ürünleri tüketimi

Rafine karbonhidrat, şeker ve şekerli içecekler

Doymuş yağlar, yüksek yağlı diyet, kırmızı et

Kümes hayvanları, balık, sebze, meyve

Yulaf, buğday kepek, bakliyat, zeytin ve tohumyağ

D vitamini, $B_{12}$ vitamini, folat, demir desteği

Fodmap (düşük/yüksek) diyet

Sulfasalazin ilaç kullanımı

Azalmış kas kütlesi/performansı

Obezlerde remisyon için

\section{Peri-operatif dönem}

Yeterli enerji/protein alamazsa

Cerrahi öncesi beslenme desteği

Cerrahi öncesi malnütrisyonlu hasta

Acil cerrahide malnütrisyonlu hasta

Enerjinin >\% 60 enteral yol ile alamazsa

Beslenme tedavisi

Cerrahi sonrası

Cerrahi sonrası uzamış gastrointestinal yetersizlik/KBS durumu

Ostomi ve fistül kayıpları

KBS, ileumdistali $>20 \mathrm{~cm}$, ileoçekal valf göre

*KBS: Kısa bağırsak sendromu **ERAS: Cerrahi sonrası hızlandırılmış iyileşme (enhanced recovery after surgery)
Sürekli, düzenli değerlendirme

Oral beslenme desteği/enteral beslenme uygulanmalı

Sürekli yüksek olmamalı/gereksinim kadar verilmeli

Sürekli kullanılmamalı

Tolerasyon varsa teşvik edilmeli

Sinırlandırılmalı/kaçınılmalı

Sinırlandırılmalı/kaçınılmalı

Arttirılmalı

Arttırılmalı (çözünür posa)

Eksikliğine göre yapılmalı

Tolerans, semptom iyileşmesine göre

Folat desteği yapılmalı

Uygun fiziksel aktivite önerilmeli

Vücut ağırlığının azaltılması önerilir.

Oral beslenme destekleri eklenmeli

En az 7 gün yapılmalı ve Cerrahi Sonrası Hızlandırılmış İyileşme

(ERAS**) protokolü uygulanmalı

En az 5 gün beslenme desteği

7 gün oral alamayacaksa enteral/parenteral beslenme planı

Total parenteral beslenme eklenmeli

Oral + enteral + parenteral beslenme birlikte yönetilmeli

Erişim yolu bağımsız erken başlanmalı

İlk aşamada total parenteral beslenme zorunludur.

Sıvı/elektrolit ekleme(Na, K, Ca, Mg, P)

$\mathrm{B}_{12}$ vitamini desteği yapılmalı 
Hastanın ilk 5 gün oral beslenmesi kesilmiş, sadece sıvı elektrolit dengesi sağlanmıştır. Postoperatif dönemde 5. gün sonrası ilk 3. günde, rejim 1 ve TPN 1 formül ile beslenmiş, ileostomisi işlemeye başlanmış, gelen 3-3.5 L ve çok sulu olup hasta mobilize olmuştur. TPN'e majör abdominal cerrahide malnütrisyondan bağımsız immünonutrisyon önerildiğinden, immünonutrisyon (glutamin, eser element, balık yağı), elektrolit eklenmiştir.

Oral alımın 4. günde rejim 2 ve CH'a uygun oral enteral ürün (günde $1 \mathrm{kez}$ : düşük osmolariteli, orta zincirli yağ asidi [MCT] içeren, remisyonu sağlayan, antiinflamatuvar etkili, dönüştürücü Büyüme
Faktörü- $\beta 2$ [TGF- $\beta 2$ ] içeren, büyüme gelişmeyi devam ettiren [5 ölçek $200 \mathrm{kkal}, 7.2 \mathrm{~g}$ protein]), TPN 2 formülü başlanmıştır. Kısa bağırsak sendromu (KBS) nedeniyle mikro besin ögeleri kayıpları artmıştır. İleostomi torbasından gelen içerik oral yoldan alınan besinlerle uyumlu bulunmuştur (sindirim, emilim yok/çok az). Yedinci günden itibaren rejim 2-3 yumuşak, düşük posalı diyet başlanmış, TPN 2 formuna, özel enteral ürüne devam edilmiştir. 15. günde ileostomi bakım eğitimi yapılmış, TPN, enteral ürün kesilmiş, rejim 2-3 yumuşak az posalı diyet düzenlenmiştir. Hastanın beslenme tedavi süreci Tablo 2'de, kullanılan parenteral beslenme solüsyonları Tablo 3’te özetlenmiştir.

Tablo 2. Hastanın beslenme tedavisi süreci

\begin{tabular}{|c|c|c|c|c|}
\hline Süre & Diyet & Enerji (kkal/gün) & Protein (g/gün) & Toplam \\
\hline İlk 3 gün & Rejim 1 & 50 & 0 & \\
\hline İlk 3 gün & TPN 1 & 1367 & 81 & 1417 kkal/gün- 81 g/gün protein \\
\hline 4.-15. gün & TPN 2 & 1367 & 104 & 2067 kkal/gün-134 g/gün protein \\
\hline 7.-15. gün & Rejim 2-3, $\downarrow$ posa & 850 & 40 & \\
\hline
\end{tabular}

Tablo 3. Total parenteral beslenme solüsyonlarının bileşimleri

\begin{tabular}{lll}
\hline & TPN $\mathbf{1}$ formu & TPN 2 formu \\
\hline Toplam miktar & $3000 \mathrm{~mL}$ & $3000 \mathrm{~mL}$ \\
\%30 dekstroz & $850 \mathrm{~mL}$ & $850 \mathrm{~mL}$ \\
\%20'lik lipit & $250 \mathrm{~mL}$ & $250 \mathrm{~mL}$ \\
\%10'luk aminoasit & $850 \mathrm{~mL}$ & $1100 \mathrm{~mL}$ \\
Elektrolitli sıvı & $850 \mathrm{~mL}$ & $600 \mathrm{~mL}$ \\
Non-protein enerji & $1367 \mathrm{kkal}$ & $1367 \mathrm{kkal}$ \\
Protein & $81 \mathrm{~g}$ & $104 \mathrm{~g}$ \\
Yağ & $\% 37$ & $\% 37$ \\
Osmolarite & $850 \mathrm{mOsm} / \mathrm{L}$ & $900 \mathrm{mOsm} / \mathrm{L}$ \\
Vitamin & Tek doz & Tek doz \\
Eser element & Tek doz & Tek doz \\
Glutamin & $13.6 \mathrm{~g}$ & $13.6 \mathrm{~g}$ \\
KCl & $60 \mathrm{mEq}$ & $60 \mathrm{mEq}$ \\
MgSO & $12 \mathrm{mEq}$ & $12 \mathrm{mEq}$ \\
Ca ${ }^{+2}$ & $4.8 \mathrm{mEq}$ & $4.8 \mathrm{mEq}$ \\
Ek olarak & $1000 \mathrm{~mL} \mathrm{izotonik} \mathrm{solüsyon}$ & $1000 \mathrm{~mL} \mathrm{izotonik} \mathrm{solüsyon}$ \\
\hline
\end{tabular}


Hastaya, mide koruyucu, kan sulandırıcı, antiinflamatuvar-antienfektif, immünosüpresif, romotoid artirit ve remisyon sağlayan ilaç ve kalsiyum, magnezyum, D vitamini desteği verilmiştir.

Hasta 1 hafta sonra ileostomiden aşırı sıvı kaybı (4-5 L), bilinç bulanıklığı, halsizlik, sürekli kusma, karın ağrısı, hareket etmede güçlük, aşırı düşkünlük ile acile gelmiş ve gastroenteroloji servisine yatış yapılmıştır. Tetkiklerde, aktif $\mathrm{CH}$ ile uyumlu bulunmamış, batın içi abse, şiddetli sıvı kaybı, beslenme yetersizliği mevcut olup vücut ağırlığ 44 kg’a düşmüştür. Hastanın Na, K, $\mathrm{Ca}, \mathrm{Mg}$, kan şekeri, Hb, Htc, D vitamini, $\mathrm{B}_{12}$ vitamini, folik asit, albümin düzeyleri düşük olup, AST, ALT, alkalen fosfataz, gama glutamil transferaz (GGT), bilirubin, kan üre azotu (BUN), kreatin düzeyleri yüksektir, vücut ağırlığı kaybının \%45'e ulaşması ve batın içi abse nedeniyle beslenme tedavisi planlanmıştır.

CH ile uyumlu sindirimi kolay-yumuşak, başlangıç için düşük posalı rejim 2-3 diyet+oral özel enteral ürün+immünonutrisyon+TPN bir arada düşünülmüştür. Reaktif hipoglisemi, bulantı olması nedeniyle az, sık aralıklı beslenme planlanmış ve rafine şeker kısıtlanmıştır. Hipovolemi nedeniyle BUN ve kreatin düzeyleri yüksektir ve hastada derecede beslenme yetersizliği saptanmıştır.

Hastanın günlük sıvı kaybı 5.5 L olup, enerji gereksinmesi= $44 \mathrm{~kg} \times 35 \mathrm{kkal}=1540 \mathrm{kkal} /$ gün Protein= $44 \mathrm{~kg} \times 5 \mathrm{~g}=110 \mathrm{~g} / \mathrm{gün}$, sıvı gereksinimi= $6 \mathrm{~L}$ olarak belirlenmiştir.

Beslenme tedavisi olarak:

- $3500 \mathrm{~mL}$ periferik TPN 3 (1080 kkal-74g protein -\%37 yağ)+1 L NaCl solüsyon

- 3×200 CH’a özel enteral ürün, 600 mL=600 kkal, 21g protein (ilk hafta üründen $200 \mathrm{~mL}$ alabilmiştir.)

- 1×1 arginin-hidroksimetil bütirat (HMB)-glutamin toz sulandırılarak oral yoldan verilmiştir.

- TPN 3 içeriği ise, \%20 dekstroz 1000 mL, \%20 lipit $200 \mathrm{~mL}, \% 8$ aminoasit $900 \mathrm{~mL}$, İsolyte-S $400 \mathrm{~mL}, 760$ mOsm/L ve ek olarak $\mathrm{Ca}+13.6 \mathrm{~g}$ glutamin+5 g n-3 yağ asidi+eser element+vitaminler şeklindedir.
Rejim 2-3 yumuşak diyete (karın ağrısı ve kramplar hafifleyince) meyve ve sebze yemeği, eklenmiştir. Süt intolerans nedeniyle yasaklanmıştır. Yemeğinin \%40’nı tüketebilmiştir (Ortalama 300 kkal- 20 g protein).

1. hafta toplam enerji ve protein $=1580 \mathrm{kkal}, 101 \mathrm{~g}$ protein

2. hafta toplam enerji ve protein= $1980 \mathrm{kkal}, 115 \mathrm{~g}$ protein

3. hafta ve 4 . hafta enerji ve protein= $1980 \mathrm{kkal}, 115$ g protein

Hasta 1 ayın sonunda 48 kg’a ulaşmış, kusması kesilmiş ve ileostomiden gelen günlük miktar $2 \mathrm{~L}$ düşmüştür. Ayrıntılı KBS ve $\mathrm{CH}$ konusunda bilgi ve diyet eğitimi yapılmış ve 1 ayın sonunda TPN kesilmiştir. Evde CH’a uygun özel enteral ürün rapor edilmiş, düzenli egzersiz önerilmiş, 6 ay sonra ileostomi kapatılması planıyla hasta taburcu edilmiştir.

Altı ay sonra vücut ağırlığı 54 kg’a ulaşmıştır. Yemeklerini ve enteral ürünlerini tüketebildiği gözlenmiştir. Ostomisi kapatılmış ve 10 günde taburcu edilmiştir.

KBS nedeniyle emilim yüzeyinin azalması ve malabsorbsiyon şiddetli yaşandığından temel besin kaynağı (\%70 kadarı) parenteral beslenme olarak planlanmıştır. Ayrıca immünonutrisyon ürün, protein kaynağı olarak hesaplanmamıştır. TPN formlarında n-6 yağ asidinin proinflamatuvar etkisi nedeniyle n-9 yağ asidi ağırlıklı, lipit içeriği ayarlanmıştır.

\section{TARTIŞMA}

$\mathrm{CH}$ ve sonrasında gelişen komplikasyonlar karmaşı bir süreçtir. Akut ataklar beslenme yetersizliğine neden olduğu gibi, cerrahi tedavilerle ilişkili komplikasyonlar mevcut beslenme tablosunu önemli derecede olumsuz etkileyebilir. Hastalık durumunda ve gelişen tüm aşamalarda beslenme durumu ve tedavisi oldukça dinamiktir, değişkendir. Klinik seyre ve hastanın durumuna göre tedavi planını her defasında yeniden düzenlemek gerekebilir. Bu olguda 
da olduğu gibi komplikasyonların yaşanmasıyla birlikte yapılan yakın izlemler doğrultusunda sıklıkla beslenme tedavisi değiştirilmiş, destek ürünleri ve farklı beslenme yolları birlikte kullanılmıştır.

Sonuç olarak, CH'ın tıbbi tedavisi beslenme tedavisiyle birlikte yürütülmeli, klinik seyir dikkatli değerlendirilmeli, enerji ve besin ögeleri gereksinmeleri iyi planlanmalıdır. Hastalığın oluşturduğu düşkünlük, gerileyen beslenme tablosu ve ciddi yetersizliklerin tedavisinde ve hastanın yaşam kalitesinin arttırılmasında beslenme tedavisi temeldir.

Çıkar çatışması - Conflict of interest: Yazarlar çıkar çatışması olmadığını beyan ederler. - The authors declare that they have no conflict of interest.

\section{KAYNAKLAR}

1. Baysoy G. İnflamatuvar barsak hastalıkları. Çocuk Gastroenteroloji, Hepatoloji ve Beslenme 2016;7:81-96.

2. Türker FP, Günaldı S. Chron hastalığı ve tıbbi beslenme. Güncel Gastroenteroloji 2016;20(3):267-273.

3. Stepanjuk P, Bernstein C, Targownik I, Singh H. Characterization of inflammatory bowel disease in elderly patients: A review of epidomiology, current practices and outcomes of current management strategies. Can J Gastroenterol Hepetol 2015;29(6):327333.
4. Malazgirt Z, Kamalı A. İnflamatuvar barsak hastalığında beslenme (Eds: Malazgirt Z, Topgül K). Nutrisyon ve gastrointestinal hastalık. 1. Baskı. Nobel Tıp Kitapevleri Ltd. Şti, İstanbul, 2011, s. 59-84.

5. Kılıçturgay S. Gastroenteroloji ESPEN enteral nutrisyon rehberi (Eds: Korfalı G, Bahar M). 1.Baskı Kepan Yayınları, 2011, s.73-84.

6. Shanahan F. Chron's disease. Lancet 2002;359(9300):6269.

7. Reimund JM, Hirth C, Koehl C, Baumann R, Duclos B. Antioxidant and immune status in active Chron's disease. A possible relationship. Clin Nutr 2000;19(1):4348.

8. Ünal H, Fırat D. İnflamatuvar hastalıklarında nutrisyon. Güncel Gastroenteroloji 2014;16(2):166-170.

9. Akpınar H. Gastroenteroloji ESPEN parenteral nutrisyon rehberi. 1.Baskı. Kepan Yayınları, 2011,s.70-83.

10. Forbes A, Escher J, Hébuterne X, Kłęk S4, Krznaric Z, Schneider S, et al. ESPEN guideline: Clinical nutrition in inflammatory bowel disease. Clin Nutr 2017;(36):321347.

11. Cresci G, Escure A. Medical nutrition therapy for lower gastrointestinal tract disorders. In: Kathleen Mahan L, Raymond J, editors. Krasues's Food \& Nutrition Care Process. 14th ed. Elseiver; 2017. p.525-559.

12. Haskey N, Glbson LD. An Examination of diet for the maintenance of remission in inflammatory bowel disease review. Nutrients 2017;9:259-279.

13. Akpınar H. İnflamatuvar barsak hastalığında nutrisyonel destek (Eds: Gündoğdu H). Klinik Nutrisyon Temelleri. 4. Baskı. Pelin Ofset Tipo Matbaacılık San. ve Tic. Ltd. Şti, Ankara, 2013, s. 458-466. 